birth or later, and frequently associated with cerebral degeneration producing idiocy. It is a not infrequent cause of congenital blindness.
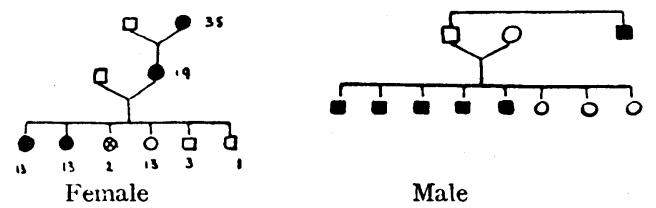

CHARTS 27A and 27b.-Amaurosis sex-linked (Sedgwick).

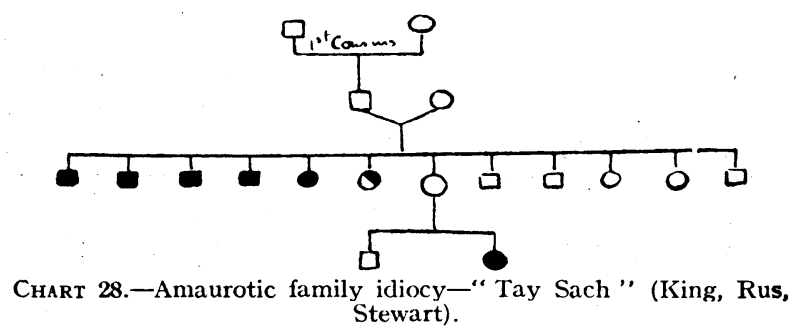

Night- and Day-Blindness

Night-blindness is due to a defect of the rod vision (colourless vision). At dusk these cases are blind, though their sight is normal in good daylight. The famous Nougaret pedigree, by Nettleship, shows 135 affected persons out of 2,116 in nine generations (a dominant heredity). There are also a recessive sex-linked type, which is regularly associated with myopia, and one or more simple recessive types (Switzerland, Japan).

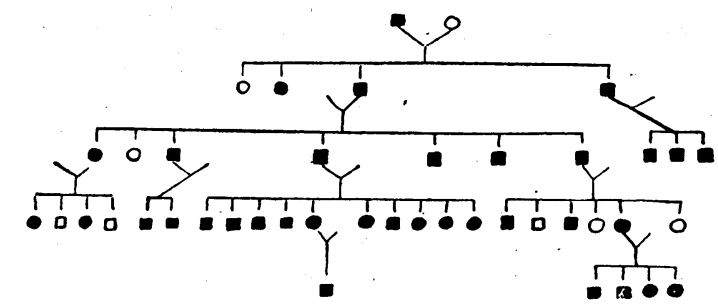

Chart 29.-Progressive night-blindness. Death sixteen months after compete blindness (Bordley).

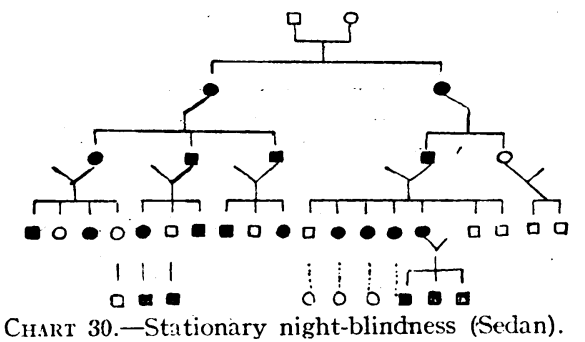

Day-blindness is a cone vision defect; such cases are colour-blind and also of " blind standard."

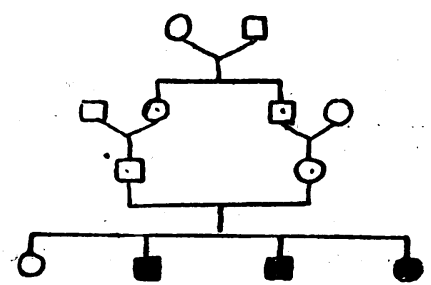

Chart 31.-Day-blind (Hessberg).

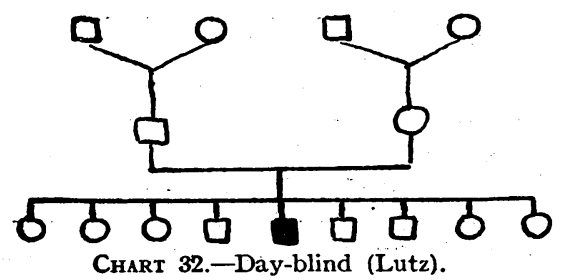

\section{Possible Remedies}

The cost in misery and unhappiness of this state of affairs is appalling, and the cost in money (potential happiness) runs into millions. Are we justified in looking on complacently or are we blameworthy? Our aims are to prevent blindness by improving environment and heredity. Here are some of the means available.

1. Constructive birth control to avoid overcrowding and poverty.

2. Sterilization of mental defectives (and possibly certain criminals) as in America.

3. Review of the obsolete and ancient abortion laws, seventy years old. They are no longer effective, and are acting deleteriously and dysgenically. Abortion should act as a second line of defence to conception control, as in - Russia.

4. Euthanasia for infants with gross defects to be available for parents who wish to make use of it.

5. Segregation of the mentally defective is difficult owing to the cost; some 300,000 are now at large.

6. The Catholics recommend control of marriage for the mentally defective, but this does not prevent illegitimacy.

7. The Wassermann reaction during or before pregnancy. This is done in Rumania before marriage.

In Mexico the State of Vera Cruz has put into effect laws for the legalization of birth control, sterilization of certain criminals and mental defectives, prevention of hereditary ailments where practicable, and the prevention of marriage by persons who are mentally deficient or physically or economically unfitted to have children. How long must we in England continue with our present inhuman methods?

\section{THE CLASSIFICATION OF THE BODY CONSTITUENTS BY WATER CONTENT*}

BY

HAROLD G. CLOSE, M.D.LOND.

ASSISTANT BACTERIOLOGIST AND LATE GRIFFITHS DEMIONSTRATOR OF PATHOLOGY, GUY'S HOSPITAL

For the sake of convenience it has been customary to describe the body by regions (anatomy), systems (physio$\operatorname{logy}$ ), or origin from embryonic layers (embryology), but for biochemistry there appears to be no such simple grouping. To remedy this deficiency a classification based on water content has been made and is presented here. Water deserves to be singled out for distinction because of its unique position in the economy of the body, both in the past and now. Besides being at one time the only medium in which life existed, it now forms the greater part of all living tissues, and plays an essential part in most, if not all, biochemical reactions. The data from which this classification was derived were obtained partly by estimations made on the chloride and water of tissues, and partly from the literature, and have been published elsewhere. ${ }^{1}$ Unfortunately, there are still many gaps in our knowledge, but it is possible even now to see the outline of the pattern underlying the construction of tissues.

\section{The Three Tissue Groups}

If the parts of the body are considered from the point of view of their water content they will be seen to fall naturally into three groups.

A. The body fluids (extracellular).

B. The nuclear or cellular tissues.

C. The anuclear, " matrix," or supporting tissues.

* Formed part of a thesis approved by the University of London for the degree of Doctor of Medicine 
These are shown with their range of water content and the principal members of each group in Table $I$.

TABLE I.-Water Content and Designation of Three Tissue Groups

\begin{tabular}{l|c|c}
\hline Name of Group & Member & $\begin{array}{c}\text { Range of Average } \\
\text { Water Content }\end{array}$ \\
\hline $\begin{array}{c}\text { A. Body fluids (extra- } \\
\text { cellular) } \\
\text { Buclear (or cellular) } \\
\text { tissues } \\
\text { Anuclear (or support- } \\
\text { ing) tissues }\end{array}$ & $\begin{array}{l}\text { C.S.F., lymph, plasma, cent. } \\
\text { synovial fluid, etc. } \\
\text { Grey mater of nervous } \\
\text { syst:m, glands, muscles } \\
\text { Connective tissue, carti- } \\
\text { lage, bone, etc. White } \\
\text { matter of nervous system }\end{array}$ & 10 to i3 \\
\hline
\end{tabular}

The upper limits of some of the anuclear tissues may overlap with the lower limits of water content in several of the nuclear tissues, so that actually the division between Groups B and C is not so clear-cut as between Groups $A$ and $B$. On the other hand, there are important points of difference between nuclear and anuclear tissues. The reaction $(c \mathrm{H})$ of tissues of Group B is kept constant by the phenomenon of " buffering "- a property anuclear tissues do not appear to possess. ${ }^{2}$ Then the types of protein in these groups also differ-mainly nucleo-protein in the nuclear, and gelatin derivatives in anuclear tissues. But these and other characteristics may perhaps be secondary to the main distinction between the two groups -namely, the presence or absence of many nuclei. Tissues with many nuclei (Group B) contain more water than those with few, and this relationship of the nucleus to water content is seen in a striking way in cells which ultimately lose their nucleus. For example, the water content of a young nuclear red blood cell is 75 per cent. ; when mature and anuclear, the red cell contains only 65 per cent. of water. The rate of metabolism of a tissue also appears to be related to the presence of the nucleus. First, there are reasons for believing that the nucleus is closely associated with the respiration of the cell ${ }^{3}$; and secondly, the rate of metabolism in the highly cellular nuclear tissues is far greater than in the supporting tissue group (C). Warburg ${ }^{4}$ was very doubtful if respiration or glycolysis occurred at all in this latter type of tissue. It may be said, therefore, that the greater the rate of metabolism in the tissues the higher is the water content, a principle which is seen in the process of growing old, when there is a parallel decline in both water content and active metabolism.

THEIR INTERRELATION

The relationships in the three groups between the water, chloride, hydrogen-ion concentration, sodium, potassium, and protein contents are shown diagrammatically in the figure, and summarized later in Table II.

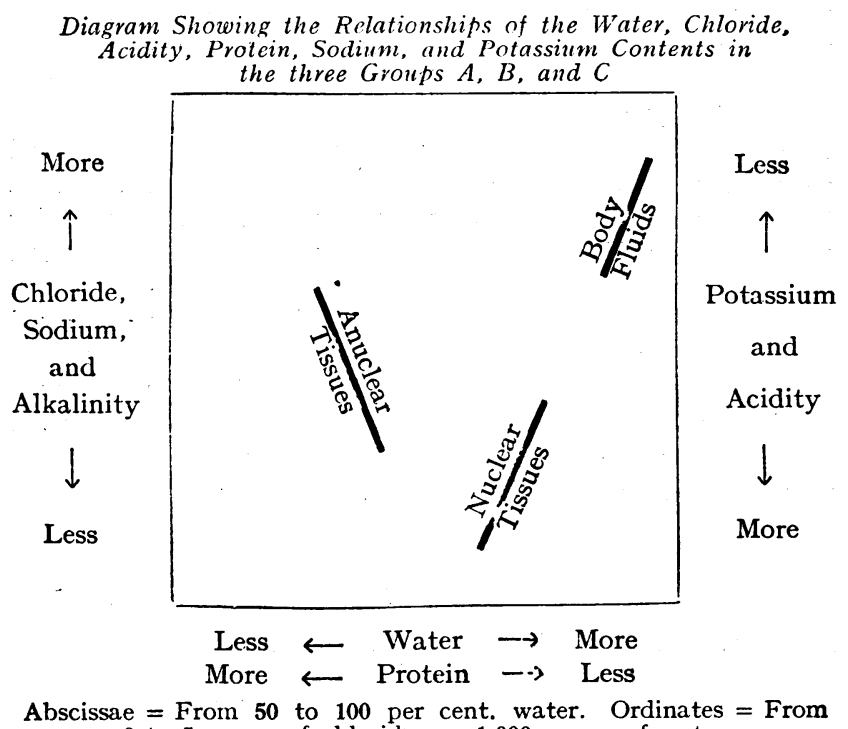

0 to 5 grams of chloride per 1,000 grams of watei.

\section{Chloride and Water}

In Groups $A$ and $B$ it is found that with an increasing amount of water there is an increasing amount of chloride. In Group C, on the other hand, this rule is reversed-with an increasing amount of water there is less chloride. No adequate reason can be given at present for this difference of chloride and water relationship in Group C, though one or two suggestions may be made. For example, it appears that the red blood cell (Group C) is enabled to hold more haemoglobin by virtue of its relatively high chloride content $\left(\mathrm{Green}^{5}\right)$. Also, if the gelatin-like proteins of the connective tissues exhibit imbibition pressure rather than osmotic pressure (as is not unlikely they do), a relatively increased amount of a salt such as $\mathrm{NaCl}$ would decrease the tendency of the protein to. " imbibe," and less water would be present. But perhaps a simpler explanation may be offered. The comparative increase of chloride with less water may be due simply to a concentration effect.

\section{Protein, Water, and Chloride}

The weight of a tissue is made up of the weights of the water present and of the so-called " solid " portion, most of which is protein. Consequently the more water there is the less protein there will be. As we know the relationship between the water and chloride in the body (see above), we can say what the relationship between the chloride and protein contents will be. In Groups $A$ and $B$ (body fluids and nuclear tissues), with more chloride there will be less protein ; in Group C (anuclear tissues), with more chloride there will be more protein. Generally speaking, these relationships are found to agree with the facts, except in the case of liver tissue and white matter, both of which are rich in lipoid bodies.

\section{Water and Hydrogen-ion Concentration}

Evidence is accumulating for the belief that the amount of chloride in a tissue or body fluid varies inversely with the hydrogen-ion concentration-that is to say, the more chloride there is, the more alkaline the tissue. Referring again to the chloride and water relationship, we may presume that in the body fluids and nuclear tissues (Groups A and B) as the amount of water increases, the acidity (or $c \mathrm{H}$ ) becomes less-that is, alkalinity increases; in the anuclear tissues (Group C) increase of water is associated with an increasing degree of acidity.

\section{Water, Sodium, and Potassium}

As the amount of chloride in a body fluid or tissue tends to vary directly with the amount of sodium and indirectly with the amount of potassium, we have once again an indication of how the sodium and potassium contents are related to the water content in the three groups. Sodium increases, potassium decreases-with increase of water in Groups A and B, but with decrease of water in Group C. Onë important exception must bs noted. The red blood cell, though classed in the anuclear group, has a relatively high chloride content and contains potassium, but no sodium.

\section{Discussion aṇD Summary}

These relationships, when grouped together as in Table II, indicate broadly how tissues and fluids arising from one cell have acquired their present chemical composition in the process of being differentiated. When more definite knowledge of the constitution of tissues becomes available it should be possible to formulate the laws which we now know exist. Marked variations from these laws might then throw light on disease processes, and particularly on the problem of selectivity of a disease for a certain tissue. It might even be an.advantage to go back to the former classification of a humoral and 
cellular pathology, but with now an additional type" matrical "-for diseases peculiar to the supporting or " matrix" tissues. Classed under the last-named heading would be such diseases as arthritis, fibrositis, neuritis, etc., about which little is known except that their pathology is unlike that of the other group diseases. But since each of the three groups A, B, and C has its own characteristic make-up (as shown above) it is not surprising that manifestations of abnormality should also be different.

The table shown below summarizes the findings discussed in the text.

\begin{tabular}{|c|c|c|c|c|c|}
\hline \multicolumn{3}{|c|}{, } & $\underset{\text { Body Fluids }}{\mathrm{A}}$ & $\underset{\text { Nuclear Tissues }}{\mathrm{B}}$ & Anuclear Tissues \\
\hline \multicolumn{3}{|c|}{ Water percentage $\ldots$} & 90 and over & 76 to 85 & Below 75 \\
\hline \multicolumn{3}{|c|}{ Rate of metabolism... } & Nil & High & Low \\
\hline \multirow{2}{*}{\multicolumn{3}{|c|}{$\begin{array}{l}\text { Concentration of } \\
\text { chloride } \\
\text { Relationship of } \\
\text { chloride to water }\end{array}$}} & High & Low & \multirow{4}{*}{$\begin{array}{c}\text { Midway between } \\
\text { Groups A and B } \\
\text { Decreases with } \\
\text { higher water } \\
\text { percentage } \\
\text { Midway between } \\
\text { Groups A and B } \\
\text { " }\end{array}$} \\
\hline & & & \multicolumn{2}{|c|}{$\begin{array}{c}\text { Inc:eases with increasing water } \\
\text { percentage }\end{array}$} & \\
\hline \multicolumn{3}{|c|}{ Relative reaction } & More alkaline & More acid & \\
\hline $\mathrm{Na} \ldots$ & ... & $\therefore$ & High & Low & \\
\hline $\mathbf{K} \ldots$ & $\ldots$ & $\ldots$ & Low & High & " \\
\hline Protein ... & $\ldots$ & $\ldots$ & Low & \begin{tabular}{|} 
Midway between \\
Groups A and C
\end{tabular} & High \\
\hline
\end{tabular}

Elsewhere I have acknowledged with gratitude the help received from many friends and from the Medical Research Council. I am also indebted to an anonymous donor for providing the greater part of the expenses of this investigation.

REFERENCES

${ }^{1}$ Close, H. G.: Biochem. Journ., 1933, xxvii, No. 4, 967.

${ }^{2}$ Rous, P., and Beattie, W. W.: Journ. Exper. Med., 1926, lxiv, 836 .

${ }^{3}$ Warburg, O., quoted by Bayliss, W. M.: Principles of General Physiology, London.

4 Warburg, O., quoted by Rous, P.: Journ. Exper. Med., 1925, xli,

739. Green, A. A.: Journ. Biol. Chem., 1932, xcv, 47.

\section{SYMPATHETIC GANGLIONECTOMY் FOR GANGRENE DUE TO THROMBO- ANGIITIS OBLITERANS}

\section{H. HAMILTON STEWART, M.A., M.B.}

B.Chir.Cantab., F.R.C.S.

HONORARY ASSISTANT SURGEON, BRADFORD ROYAL INFIRMARY : HONORARY SURGEON, BRADFORD CHILDREN'S HOSPITAL

The value of sympathetic ganglionectomy for the treatment of Raynaud's disease is well known, but doubt is still expressed as to its value in the treatment of thromboangiitis obliterans, or, as it is often called, juvenile gangrene or Buerger's disease. It is the purpose of this paper to give a brief description of this rather rare disease and to record a case treated successfully by sympathetic ganglionectomy.

\section{The Disease}

The cause of thrombo-angiitis obliterans is unknown. It usually occurs in young males between the ages of 17 and 35, and was originally considered to be almost limited to the Hebrew race: this has now been shown not to be the case. Over-indulgence in tobacco has been said to be a determining factor, but there is little evidence to support this theory. Buerger ${ }^{\mathbf{1}}$ originally suggested an inflammatory or toxic origin, and workers at the Mayo Clinic $^{2}$ have performed experiments which tend to support this view. In this disease thrombosis occurs in the larger arteries of the limbs, and, if the arterial system is extensively involved, gangrene is liable to oscur. The capillaries, arterioles, and finest arteries appear to escape. The thrombosis may affect the whole or only a portion of an artery at one time, but recurrences of the thrombosis will occur, now in this, now in that artery, until the signs of deficient blood supply to the limb become evident. The thrombus is eventually organized, and may be recanalized, and with this process some degree of periarteritis is prone to occur. The veins of the limbs may be affected in the same way.

It is interesting to note that the actual thrombosis would appear to pass unnoticed by the patient, and to be free from constitutional reactions. This was so in the case $I$ am about to describe, even though the patient had suffered from the disease in three of his limbs and was warned that the last one might be affected in the same way. It is not until the obliterative process has extended so widely as to interfere materially with the blood supply of the limb that the characteristic symptoms of the disease become manifest. The patient suffers from the result of the disease rather than from the disease itself. He (or she) complains in the first instance of a sensation of numbness and coldness in the affected limb in the cold weather, and indefinite pains, which he often considers to be rheumatic in origin. These affect particularly the arch of the foot, calf of the leg, and the wrist. The symptoms of inter= mittent claudication are complained of quite early in the history of the disease, and when the affected limb is allowed to hang down the extremity acquires a purplish blush, which gives place to excessive pallor on elevation of the limb. Degenerative changes occur in the skin and nails, the skin becoming thickened and cornified and the nails brittle and hard. Ulceration is prone to occur under the nails and in any site of local injury. Later, the patient suffers from persistent pain, and sits holding the affected limb. Gangrene eventually supervenes. On examination the affected limb is cold, and if the progress of the disease has been slow some wasting is evident. It may not be possible to feel pulsation in such arteries as the dorsalis pedis, posterior tibial (at the ankle), popliteal, radial, and ulnar arteries.

It is difficult at first to understand how sympathetic ganglionectomy can improve the blood supply to a limb when the larger arteries are blocked with organizing thrombi. It would appear to act by allowing the smaller arteries to dilate and thus improving the collateral circulation. The value of periarterial sympathectomy is known to be transitory. Now if satisfactory results are to be obtained the appropriate sympathetic ganglia corresponding to the limbs must be removed. In the case here recorded the inferior cervical and first thoracic ganglia were removed on both sides by an exposure obtained by costo-transversectomy at the level of the second rib. In this operation the transverse process of the second thoracic vertebra is removed along with about three inches of the second rib. The pleura is then depressed and a good exposure of the sympathetic chain with its branches is obtained, rather better on the left than on the right side. The desired amount of sympathetic tissue can be removed exactly, and the risk of leaving a portion of the first thoracic ganglion behind is very small. The anterior approach is difficult, the exposure often inadequate, and an incomplete operation is liable to result.

The case described below is that of a young man, aged 25 , a gentile, who had lost both lower limbs from gangrene due to Buerger's disease, and who was in imminent danger of losing both upper limbs from the same disease. By a timely sympathetic ganglionectomy on both sides it was possible to save these limbs.

\section{CASE RECORD}

The patient comes of a healthy family, and with no history of syphilis: on two occasions his Wassermann reaction was negative. At school he was the fastest runner, and was in perfect health until February, 1925, when at the age of 18 a box fell on his right foot. A phlebitis resulted, which 